"Metals futures market: a comparative analysis of investment and arbitrage strategies"

\begin{tabular}{|c|c|}
\hline AUTHORS & $\begin{array}{l}\text { Lidiya Guryanova (D https://orcid.org/0000-0002-2009-1451 } \\
\text { Natalia Chernova (D https://orcid.org/0000-0002-0073-8457 }\end{array}$ \\
\hline ARTICLE INFO & $\begin{array}{l}\text { Lidiya Guryanova and Natalia Chernova (2019). Metals futures market: a } \\
\text { comparative analysis of investment and arbitrage strategies. Development } \\
\text { Management, } 17(4), 42-54 \text {. doi:10.21511/dm.17(4).2019.04 }\end{array}$ \\
\hline DOI & http://dx.doi.org/10.21511/dm.17(4).2019.04 \\
\hline RELEASED ON & Tuesday, 03 March 2020 \\
\hline RECEIVED ON & Wednesday, 27 November 2019 \\
\hline ACCEPTED ON & Monday, 16 December 2019 \\
\hline LICENSE & $\begin{array}{l}(c) \text { EY } \\
\text { This work is licensed under a Creative Commons Attribution } 4.0 \text { International } \\
\text { License }\end{array}$ \\
\hline JOURNAL & "Development Management" \\
\hline ISSN PRINT & $2413-9610$ \\
\hline ISSN ONLINE & $2663-2365$ \\
\hline PUBLISHER & LLC “Consulting Publishing Company "Business Perspectives" \\
\hline FOUNDER & Simon Kuznets Kharkiv National University of Economics \\
\hline$\sigma^{\circ}$ & $\begin{array}{l}\text { ニニ: } \\
\text { ニ }\end{array}$ \\
\hline NUMBER OF REFERENCES & NUMBER OF FIGURES \\
\hline 17 & 11 \\
\hline
\end{tabular}

(C) The author(s) 2021. This publication is an open access article. 


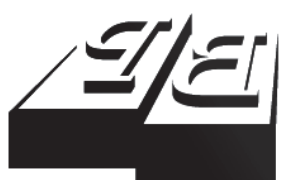

BUSINESS PERSPECTIVES

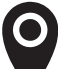

Publisher

LLC "CPC "Business Perspectives" Hryhorii Skovoroda lane, 10, Sumy, 40022, Ukraine www.businessperspectives.org

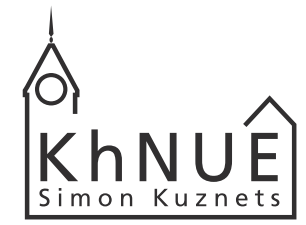

\section{S. KUZNETS KHNUE}

\section{Founder}

Simon Kuznets Kharkiv National University of Economics, Nauky avenue, 9-A, Kharkiv, 61166,

Ukraine

http://www.hneu.edu.ua/

Received on: 27 th of November, 2019

Accepted on: 16th of

December, 2019

\section{(C) Lidiya Guryanova,}

Natalia Chernova, 2019

Lidiya Guryanova, Doctor of Science, Professor of Economic Cybernetics Department, Simon Kuznets Kharkiv National

University of Economics, Ukraine.

Natalia Chernova, Ph.D., Associate Professor of Economic Cybernetics Department, Simon Kuznets Kharkiv National University of Economics, Ukraine.

\title{
METALS FUTURES MARKET: A COMPARATIVE ANALYSIS OF INVESTMENT AND ARBITRAGE STRATEGIES
}

\begin{abstract}
The article deals with the application of optimal portfolio theory and pair trading theory on the metals futures market. Advantages of the futures market over the spot market include relatively small initial price, low transaction costs, and high volatility. The main aim of the study is to explore the potential of both strategies for effective trading. The following financial instruments were chosen as the inputs of the models: futures on industrial metals (aluminum, copper, nickel, zinc, lead, tin), futures on precious metals (gold and silver). When building the optimal portfolio, it was decided to include Dow Jones Index futures and S\&P Index futures among metals. This is because these instruments are extremely volatile and may play the role of a hedge in the portfolio. A drawdown indicator was used to assess the effectiveness of each strategy. The results show that both strategies can be applied on the real-life market. The final choice will depend on the level of risk taking by investors and the desired value of return.
\end{abstract}

\section{Keywords}

JEL Classification metals market, futures, risk, return, optimal portfolio, pairs trading, model, ratio, correlation, stationarity

Л. С. Гур'янова (Україна), Н. Л. Чернова (Україна)

\section{РИНОК Ф'ЮЧЕРСІВ НА МЕТАЛИ: ПОРІВНЯЛЬНИЙ АНАЛІЗ СТРАТЕГІЙ IНВЕСТУВАННЯ ТА АРБІТРАЖУ}

\begin{abstract}
Анотація
У статті розглянуто застосування оптимальної теорії портфеля та теорії парного трейдингу на ринку ф’ючерсів на метали. Переваги ф’ючерсного ринку перед спотовим ринком включають відносно невеликупочаткову ціну, низькі транзакційні витрати, високу волатильність. Основна мета дослідження - вивчити можливості застосування обох стратегій для забезпечення ефективної торгівлі. В якості входів для моделей були обрані наступні фінансові інструменти: ф'ючерси на промислові метали (алюміній, мідь, нікель, цинк, свинець, олово), ф'ючерси на дорогоцінні метали (золото і срібло). При побудові оптимального портфеля було вирішено включити ф'ючерси на індекс Dow Jones та ф'ючерси на індекс S\&P поряд 3 ф'ючерсами на метали. Це пов'язано з тим, що ці інструменти надзвичайно волатильні і можуть виконувати роль хеджу в портфелі. Для оцінки ефективності кожної стратегії був використаний показник просадки. Отримані результати свідчать про те, що обидві стратегії можуть бути застосовані на реальному ринку. Остаточний вибір буде залежати від рівня прийняття інвесторами ризику та бажаного значення прибутку.
\end{abstract}

Ключові слова

Класифікація JEL ринок металів, ф’ючерси, ризик, прибуток, оптимальний портфель, парний трейдинг, модель, коефіцієнт, кореляція, стаціонарність

C22, C58, C61

This is an Open Access article, distributed under the terms of the Creative Commons Attribution 4.0 International license, which permits unrestricted re-use, distribution, and reproduction in any medium, provided the original work is properly cited. 


\section{INTRODUCTION}

In modern financial world derivative products play significant role on a par with spot ones. The derivatives market continues to be the largest single segment of the financial market. In recent years the global derivatives market performed march better than the global equity and bond markets combined. Historically, derivatives have shown strong growth. Derivatives today demonstrate rather high levels of liquidity and are broadly used not only as hedge instruments but also as objects of investments and arbitrage. The advantages of derivatives include a relatively small, initial investment price and relatively low transaction costs. Derivatives are traded in one of two ways: either OTC or on regulated markets, i.e. on exchanges. Exchange-traded derivatives are fully standardized. The highest amounts of metals derivatives are traded on the New York Mercantile Exchange, the London Metal Exchange and the Shanghai Futures Exchange.

When evaluating a derivative for tradability, the most important indicators to watch for are rate of return, volume and open interest, notional value (Hull, 2012; Nijman \& de Roon and Veld, 1996).

Rate of return shows the amount of value an investor earns from an asset over a specific period. It is calculated as follows:

Rate of return $=\frac{\text { Current price }- \text { Initial price }}{\text { Initial price }}$.

Volume is the total number of futures contracts traded in a market. Open interest is the total number of open long and short positions in a market The higher the volume and open interest, the more liquid a contract is. Notional value is the total underlying amount of a derivatives trade. The notional value of derivative contracts is much higher than the market value due to leverage.

Derivatives markets are usually divided on sections depending on the such classes of underlying asset as equity, fixed-income instrument, commodity, currency and credit event. This research is devoted to the metal futures subsection of the commodity market.

Figure 1 shows the average daily notional values for derivative contracts by major markets [4]. It should be noted that the highest values were demonstrated by the interest rates section (6100 bln of dollars). But it was not drawn on the figure because of the scale. Metals section has demonstrated 76 bln amount. It is the third after agriculture and FX sections. Its notional value accounts for approximately $92 \%$ of agriculture section and almost equal to the FX section. So the liquidity of the metals section is comparably high for obtaining profit.

Metal futures are usually classified on precious and non-precious groups. Precious metals are rare and can be used in currencies or for industrial needs. The most common precious metals markets are gold, silver, platinum and palladium. Non-precious group usually include aluminum, copper, lead, nickel, tin and zinc.

Figure 2 shows the daily volumes for top six metals futures on CME (CME Group, n.d.). The significant part of volume is generated by precious group (81.77\%), the last $18.23 \%$ accounted for base metals.

Daily volumes for top six metal futures on LME are presented on Figure 3 (CME Group, n.d.). Here we can see that the absolute leaders are from the non-precious group.

Both Figure 2 and Figure 3 testify about rather high level of liquidity of the metals futures market. If you classify deals with derivative products by the goal, agreements that aim to hedge your risk should first be mentioned. However, due to the general growth of the futures market, derivatives are increasingly being used not only for direct risk insurance but also for investment and arbitrage strategies. Investment deals aim to profit from the difference between the opening price and the closing price. Arbitrage operations, unlike the first ones, are marketneutral, because their outcome does not depend on the overall direction of the markets. Both strategies today are broadly used on the spot metals markets. So because of the strong relationships between the spot market and the futures market we assume the existence of trading opportunities on the last one. 


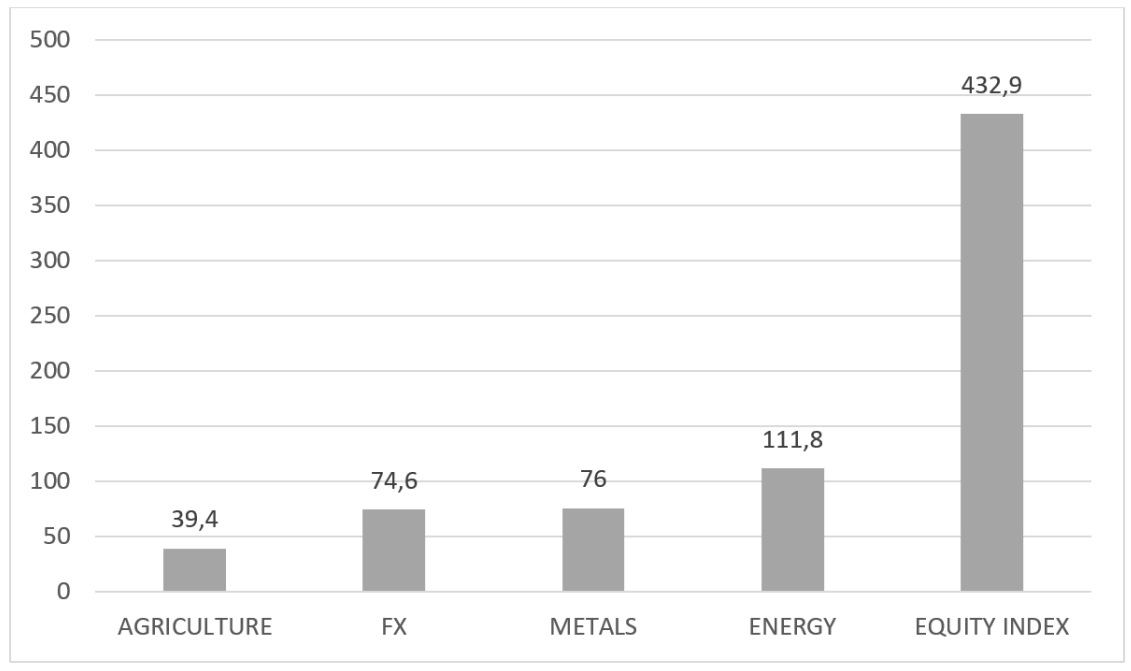

Source: Developed by the authors based on the [2].

Figure 1. Average daily notional value, October 2019 (in blns of dollars)

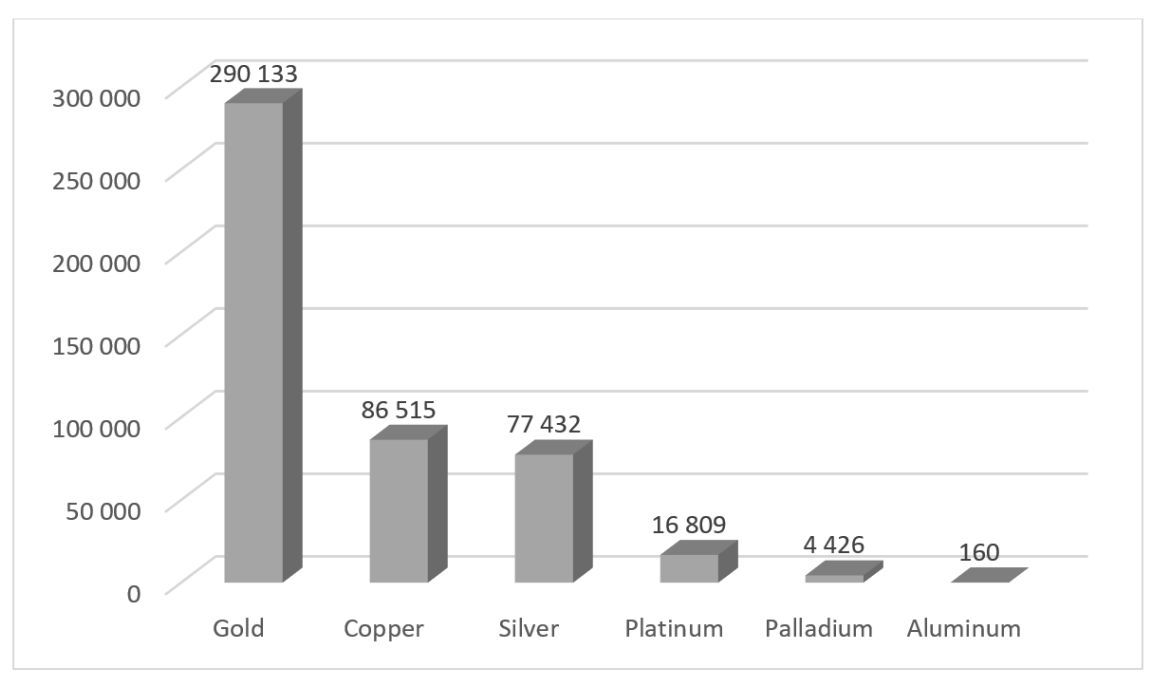

Source: Developed by the authors based on the [2]

Figure 2. Daily volume for top six metal futures on CME

To examine this hypothesis about metals futures market firstly we intend to apply the modern quantitative methods and construct the model for choosing the optimal set of assets that should be included into the investing portfolio. Secondly, we will test the possibilities of applying mean reverting strategy for the given set of futures pairs. Lastly, the results obtained on the first and the second steps should be compared to make the final conclusion about the efficiency of investment and arbitrage strategies.

\section{LITERATURE REVIEW}

Let's consider both mentioned above strategies. Investment strategy - a strategy for allocating capital among different categories to gain profit (Mangram, 2013; Markowitz, 1952; Vollmer, 2015; Sharpe, 1964; Tobin, 1969). The strategy should take into account the investor's risk tolerance as well as future needs for capital. Risk tolerance is the amount of risk that an investor is able to handle. The rate of return information can be used to help the investor decide upon the types of investments to engage in and the level of risk to take on. This strategy can be applied on the basis of so cold portfolio theory - the theory of investment management, based on statistical methods for optimizing the portfolio structure according to the selected criterion for the ratio of profitability and risk. 


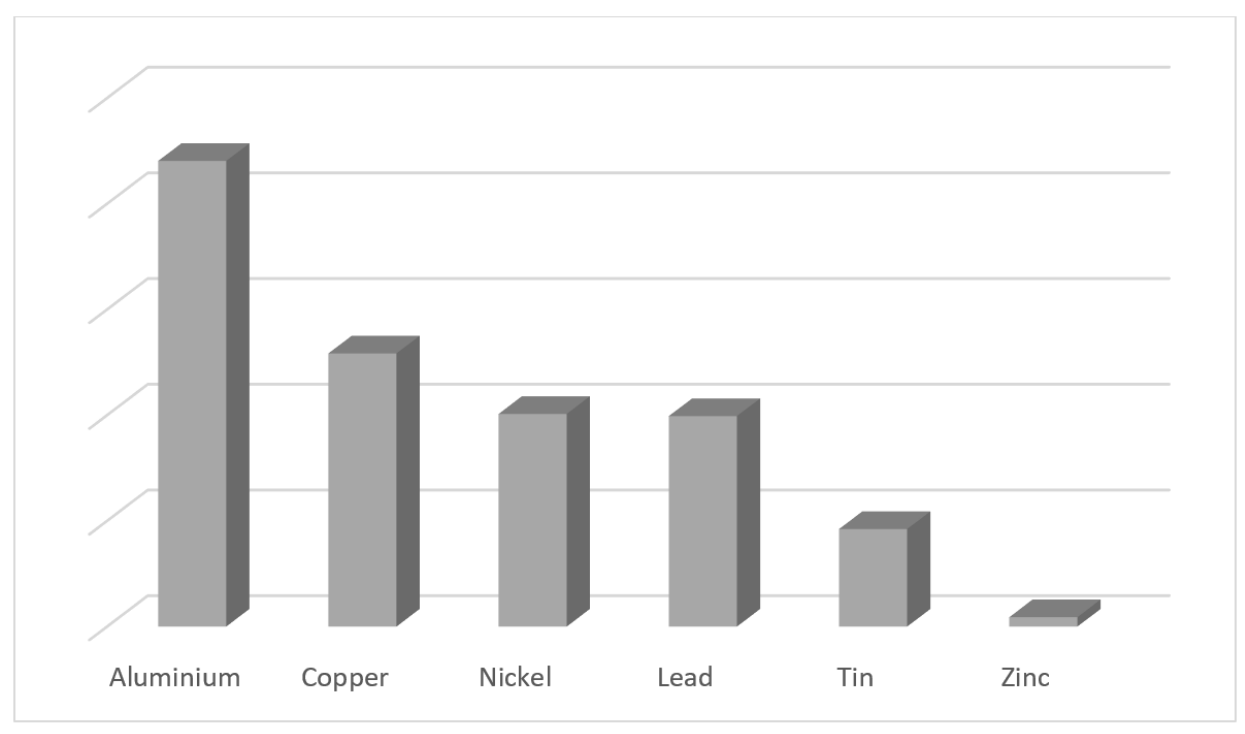

Source: Developed by the authors based on the [2].

Figure 3. Daily volume for top six metal futures on LME

Markowitz (1952) was the first who formulate the portfolio theory core principals. He offered a mathematical model for the formation of an optimal portfolio of securities, and also gives methods for constructing such portfolios under certain conditions. Instead of focusing on the risk of each individual asset, Markowitz demonstrated that a diversified portfolio is less volatile than the total sum of its individual parts. While each asset itself might be quite volatile, the volatility of the entire portfolio can actually be quite low. The problem is solved by quadratic optimization methods. The only problem here is that these methods are applicable only for comparatively low dimensional tasks.

While Markowitz suggested to form optimal portfolio of stocks only, Tobin (1969) later proposed to include riskfree assets (government bonds) in the initial set of securities. In fact, his approach is macroeconomic, since in this case the main object of study is the distribution of total capital into two forms: cash and non-cash.

The main result of capital asset pricing model (CAPM) was the establishment of a ratio between profitability and asset risk for market equilibrium. It was postulated that risk of any asset consists of two parts - non-systematic and systematic. When choosing an optimal portfolio investor should take into account only systematic or nondiversifiable risk (Sharpe, 1964).

Arbitrage strategy is based on making profit from the price difference between two or more interrelated assets (Do \& Faff, 2010; Elliott \& van der Hoek and Malcolm, 2005; Fernholz \& Maguire, 2007; Gatev, Goetzmann \& Rouwenhorst, 2006; Stübinger \& Bredthauer, 2017; Vidyamurthy, 2004; Göncü \& Akyildirim, 2016; Chen, Cui, Gao \& Leilei, 2018; Krauss, 2017). The essence of all arbitrage strategies is to search for price imbalances between a group of interconnected financial instruments, and to conduct simultaneous trading operations in the direction of eliminating these imbalances. The arbitrage can be deterministic or statistical. Deterministic arbitrage implies that a fundamental connection between the instruments exists. Statistical arbitrage relies on just a statistical relationship between instruments, based usually solely on historical observations and back testing.

The core steps of arbitrage strategy are the following:

- identifying the set of instruments, which are suitable for arbitrage;

- detecting the entry-exit points for the strategy. 
These steps may be carried out by different algorithms. Gatev (2006) suggested the distance method for finding arbitrage pairs. The distance here is calculated for normalized price series. Some authors suggest correlation coefficient as distance measure.

Vidyamurthy (2004) suggested a co-integration approach. It is based on first estimates the linear relationship between two series and then tests their spread for stationarity.

Specifying the entry-exit points for the strategy is usually based on calculating of spread variance. When the spread deviates from the fair level (from the average), it is recommended to sell or buy the spread in the direction of a fair statistical average.

\section{AIMS}

The main aim of this research is to analyze opportunities of applying investing and arbitrage trading strategies on metals futures market. To achieve the aim, the following tasks will be solved:

- construct optimal Markowitz portfolio for a given set of futures;

- form suitable pairs of metals futures that allow to trade arbitrage strategy;

- compare the effectiveness of both mentioned types of trading strategies.

\section{METHODS}

The classical Markowitz (Markowitz, 1952; Vollmer, 2015) model takes into consideration the following basic assumptions: investors are rational and seek to maximize the expected return; investors are risk averse so they require a higher expected return to compensate for higher risk accepted; investors rely merely on expected returns and variance to make investment decisions; investors cannot influence prices; risk is estimated as the standard deviation of return.

Portfolio return is calculated as the weighted average sum of the returns of individual securities:

$$
R_{p}=\sum_{i} w_{i} r_{i}
$$

where $w_{i}$ - weight of the $i$-th instrument, $r_{i}$ - return of the $i$-th instrument.

Portfolio risk is calculated as following:

$\delta_{p}^{2}=\sum_{i} w_{i}^{2} \delta_{i}^{2}+\sum_{i} \quad \sum_{j \neq i} w_{i} w_{j} \delta_{i} \delta_{j} \rho_{i j}$

where $\delta_{i}^{2}$ - risk of the i-th instrument, $p_{i j}$ - the correlation coefficient between the returns on instruments $i$ and $j$.

In order to form a portfolio, it is necessary to solve the optimization problem that can be presented in the following two forms.

Problem 1 - finding shares in a portfolio to achieve maximum efficiency at a given level of risk $\delta_{\text {norm }}^{2}$ :

$\sum_{i} w_{i} r_{i} \rightarrow \max$,

$\sum_{i} w_{i}^{2} \delta_{i}^{2}+\sum_{i} \quad \sum_{j \neq i} w_{i} w_{j} \delta_{i} \delta_{j} \rho_{i j} \leq \delta_{\text {norm }}^{2}$,

$\sum_{i} w_{i}=1, \quad w_{i} \geq 0$. 
Problem 2 - finding shares in a portfolio to achieve minimum risk at a given level of portfolio return $r_{\text {norm }}$ :

$\sum_{i} w_{i}^{2} \delta_{i}^{2}+\sum_{i} \quad \sum_{j \neq i} w_{i} w_{j} \delta_{i} \delta_{j} \rho_{i j} \rightarrow \min$

$\sum_{i} w_{i} r_{i} \geq r_{\text {norm }}, \quad \sum_{i} w_{i}=1, \quad w_{i} \geq 0$.

The model allows to obtain the so-cold efficient frontier - a set of portfolios that give us the highest return for the lowest possible risk.

Pair trading algorithm includes the following steps (Elliott \& van der Hoek and Malcolm, 2005; Gatev, Goetzmann \& Rouwenhorst, 2006; Krauss, 2017):

Step 1. Detecting pairs for trading.

In this study, the decision on pairs structure is made based on the analysis of the correlations matrix. We will take into consideration those pairs for which the appropriate correlation coefficient accedes 0.9 .

Step 2. Spread or ratio calculation.

Spread is calculated as a difference between two prices, and the ratio is obtained when you divide one price into another. Here we will calculate the ratios.

Step 3. Determining the threshold values of the ratio.

After the ratio is calculated, it is necessary to determine the optimal value of the deviation at which it will be bought or sold. In this case, if you choose too small values, it is possible to obtain a substantial drawdown of capital and a small profit, and if too large, the number of transactions can be reduced significantly.

Step 4. Determining performance indicators for a strategy.

There are such popular indicators for assessing a strategy as net profit, profit factor, authentic profit factor, percent profitable, average trade net profit, maximum drawdown. We will use the last one - maximum drawdown indicator. It measures the drop from peak to bottom in the value of a portfolio (before a new peak is achieved) and is calculated as follows:

- when the ratio is being bought:

Drawdown $=\frac{\text { Open_price }- \text { Lowest_value_before_deal_is_closed }}{\text { Open_price }}$.

- when the ratio is being sold:

Drawdown $=\frac{\text { Highest_value_before_deal_is_closed }- \text { Open_price }}{\text { Open_price }}$.

Drawdown indicator will help us to compare the historical risk of different strategies.

\section{RESULTS AND DISCUSSION}

Let's consider the models application for the following financial instruments: futures on industrial metals (aluminum, copper, nickel, zinc, lead, tin) and futures on precious metals (gold and silver). When constructing the optimal Markowitz portfolio, we will include Dow Jones Index futures (INDU index) and S\&P Index futures (SPX Index) among with metals. This is due to the fact that these instruments are extremely volatile and may play the role of hedge in the portfolio. Input data are the daily series of close prices for time period 1997-2019 (CME Group, n.d.). 
Table 1 demonstrates pair correlation coefficients for researched assets.

Table 1. Correlation coefficients

Source: Developed by the authors based on the [2]

\begin{tabular}{|c|c|c|c|c|c|c|c|c|c|c|}
\hline & aluminum & copper & nickel & zinc & lead & $\operatorname{tin}$ & $\begin{array}{l}\text { INDU } \\
\text { Index }\end{array}$ & $\begin{array}{l}\text { SPX } \\
\text { Index }\end{array}$ & silver & gold \\
\hline aluminum & 1.00 & - & - & - & - & - & - & - & - & - \\
\hline copper & 0.80 & 1.00 & - & - & - & - & - & - & - & - \\
\hline nickel & 0.86 & 0.72 & 1.00 & - & - & - & - & - & - & - \\
\hline zinc & 0.77 & 0.79 & 0.69 & 1.00 & - & - & - & - & - & - \\
\hline lead & 0.69 & 0.92 & 0.62 & 0.77 & 1.00 & - & - & - & - & - \\
\hline $\operatorname{tin}$ & 0.57 & 0.90 & 0.47 & 0.63 & 0.90 & 1.00 & - & - & - & - \\
\hline INDU Index & 0.20 & 0.45 & 0.06 & 0.61 & 0.58 & 0.58 & 1.00 & - & - & - \\
\hline SPX Index & 0.14 & 0.38 & 0.01 & 0.58 & 0.52 & 0.52 & 0.99 & 1.00 & - & - \\
\hline silver & 0.54 & 0.86 & 0.47 & 0.51 & 0.78 & 0.90 & 0.35 & 0.28 & 1.00 & - \\
\hline gold & 0.42 & 0.84 & 0.35 & 0.58 & 0.84 & 0.93 & 0.61 & 0.54 & 0.91 & 1.00 \\
\hline
\end{tabular}

According to the Table 1 there are not strong relationships between index futures and metals futures. From the other hand, interrelations between non-precious metals are rather high - the majority of the coefficients accede 0.75 .

Figure 4 shows the relations between average levels of risk and return for all assets. It can be seen that there are approximately three asset groups. Aluminum, gold, SPX index and INDU index form the first group with the lowest levels of risk. Nickel is the second asset with the highest return and it has the highest risk. It forms the second group. The others may be positioned into the third group with middle level of risk and rather high return.

So, the initial set of derivatives are from different asset classes (precious metals, non-precious metals and equity indexes), their time series have demonstrated different levels of risk and return and low correlations between classes. That is why there are fundamental and statistical grounding to include them into initial portfolio.

The resulting ten portfolios are presented in the Table 2. Figure 5 shows the efficient frontier for obtained set of portfolios.

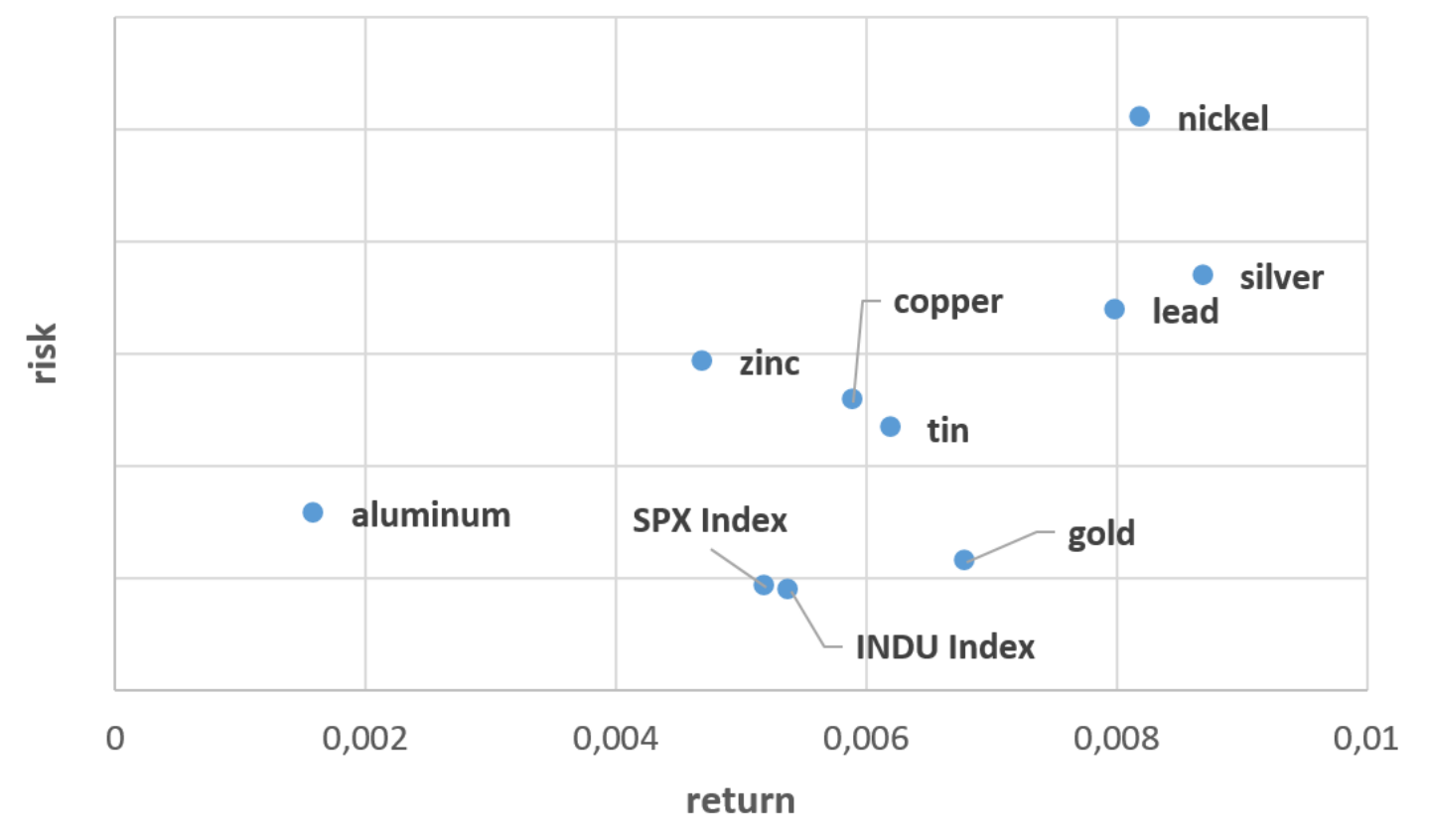

Figure 4. Average risk and return 
Table 2. Portfolio members, risk and return

Source: Developed by the authors.

\begin{tabular}{|c|c|c|c|c|c|c|c|c|c|c|}
\hline \multirow{2}{*}{ Instrument } & \multicolumn{10}{|c|}{ Portfolio } \\
\hline & P1 & P2 & P3 & P4 & P5 & P6 & P7 & P8 & P9 & P10 \\
\hline aluminum & 0.0864 & 0.0213 & 0.0000 & 0.0000 & 0.0000 & 0.0000 & 0.0000 & 0.0000 & 0.0000 & 0.0000 \\
\hline nickel & 0.0000 & 0.0000 & 0.0000 & 0.0283 & 0.0583 & 0.0864 & 0.1127 & 0.1344 & 0.1560 & 0.0000 \\
\hline lead & 0.0000 & 0.0168 & 0.0892 & 0.1655 & 0.2073 & 0.2466 & 0.2808 & 0.3022 & 0.3235 & 0.0000 \\
\hline tin & 0.0242 & 0.0410 & 0.0328 & 0.0081 & 0.0000 & 0.0000 & 0.0000 & 0.0000 & 0.0000 & 0.0000 \\
\hline INDU Index & 0.4864 & 0.5055 & 0.4090 & 0.2724 & 0.1725 & 0.0720 & 0.0000 & 0.0000 & 0.0000 & 0.0000 \\
\hline SPX Index & 0.0104 & 0.0000 & 0.0000 & 0.0000 & 0.0000 & 0.0000 & 0.0000 & 0.0000 & 0.0000 & 0.0000 \\
\hline silver & 0.0000 & 0.0000 & 0.0000 & 0.0000 & 0.0536 & 0.1123 & 0.1976 & 0.3501 & 0.5026 & 1.0000 \\
\hline gold & 0.3925 & 0.4155 & 0.4690 & 0.5257 & 0.5082 & 0.4826 & 0.4089 & 0.2133 & 0.0178 & 0.0000 \\
\hline risk & 0.0311 & 0.0313 & 0.0323 & 0.0355 & 0.0400 & 0.0453 & 0.0511 & 0.0579 & 0.0658 & 0.0860 \\
\hline return & 0.0056 & 0.0060 & 0.0063 & 0.0067 & 0.0070 & 0.0073 & 0.0077 & 0.0080 & 0.0084 & 0.0087 \\
\hline
\end{tabular}

For P1 portfolio risk equals 0.0311 and return is 0.0056 . Its core participants are INDU Index (48.64\%) and gold (39.25\%). The remaining $12.11 \%$ are occupied by aluminum, tin and SPX Index. In two subsequent portfolios with a higher risk level we can see the decline in the share of aluminum (from 8.64\% to 0\%) and SPX Index (from $1.04 \%$ to $0 \%$ ). Simultaneously the lead has become the participant of the portfolio, the other assets have shown the increase in its share. P4 portfolio is characterized by the highest share of gold (52.57\%).

According to Figure 6, the total share of both gold and INDU Index futures accedes 55\% for the first six portfolios. It is falling rapidly beginning from the seventh portfolio, partially due to the absence of index futures in portfolios P7-P10. Gold is present in all portfolios except P10. When its share decrease it is partly replaced by silver. The share of nickel and lead grow with the increase in total portfolio risk.

Two assets haven't appeared in any portfolio. They are copper and zinc.

There is a point on the efficient frontier that has the maximum value of the Sharpe ratio. Its coordinates are (risk=0.0319; return=0.0063). The appropriate portfolio consists of lead (7.29\%), tin (3.60\%), INDU Index (43.37\%) and gold (45.73\%). The maximum drawdown for this portfolio equals $34 \%$.

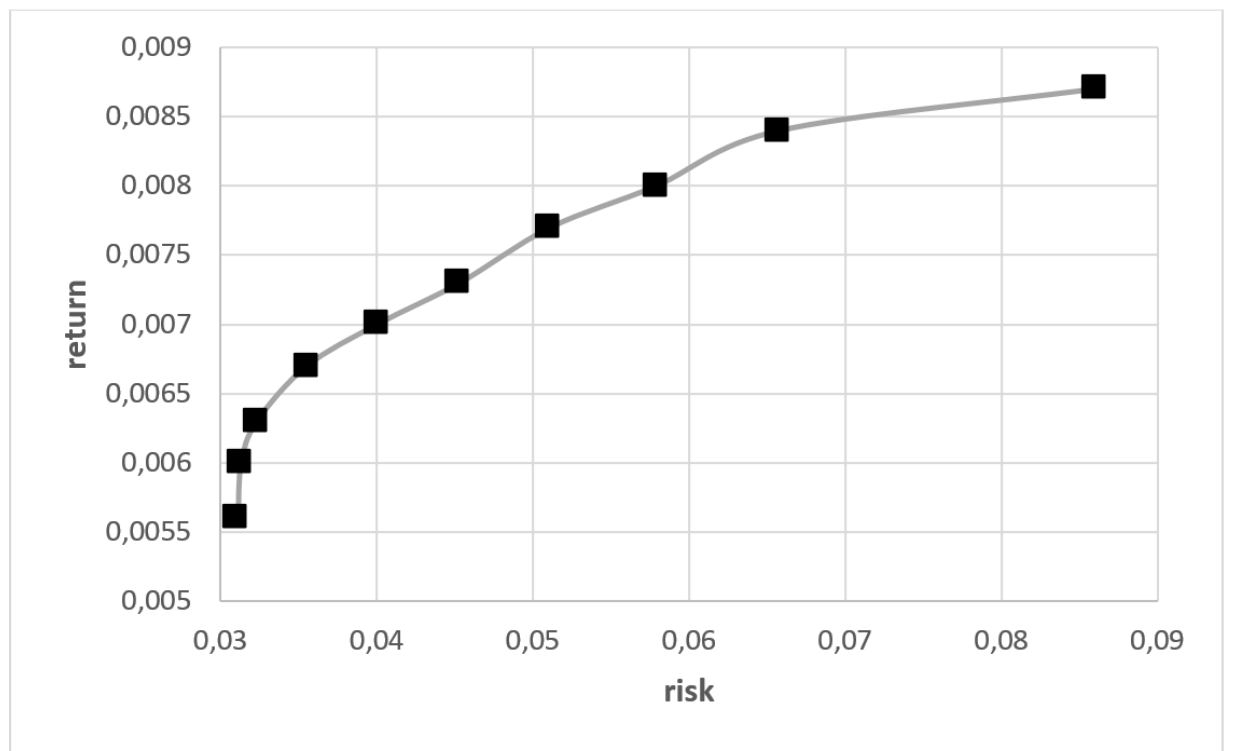

Figure 5. Efficient frontier 


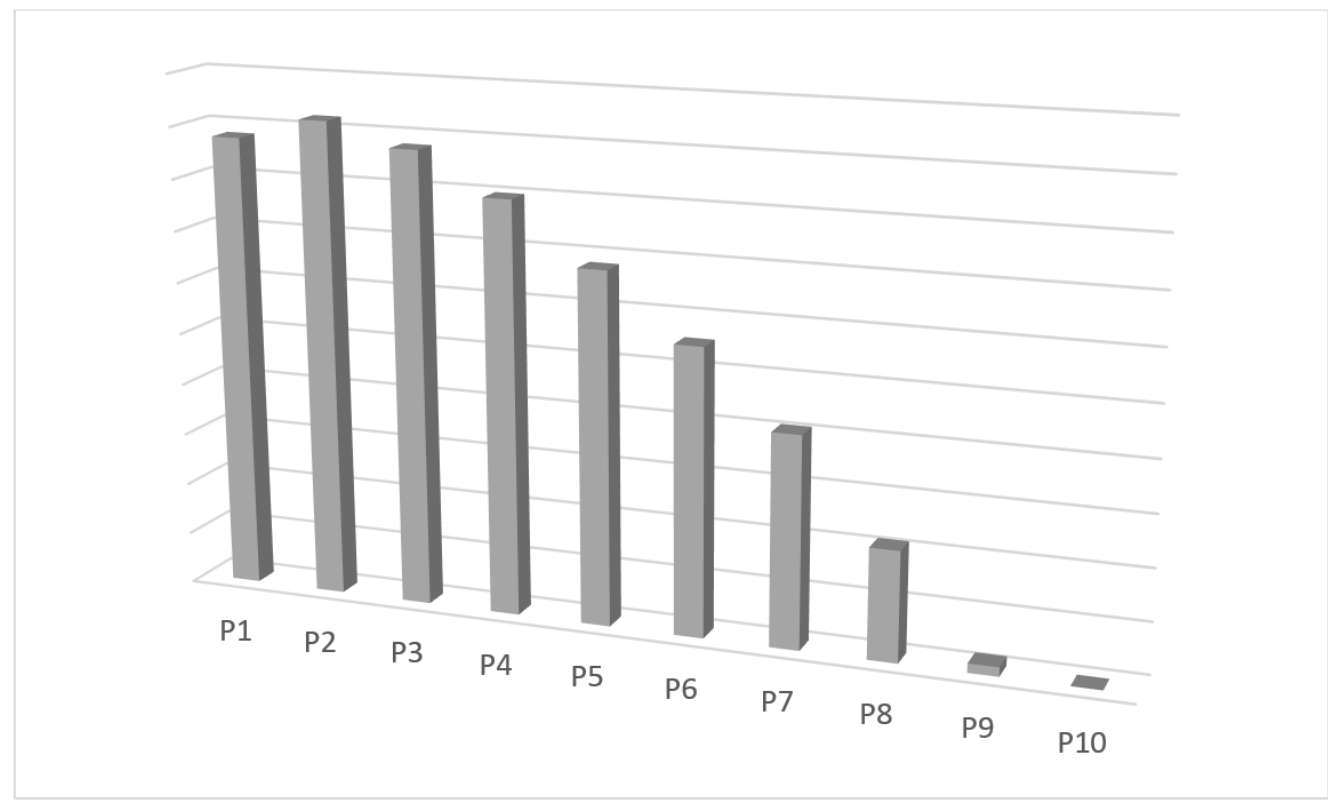

Source: Developed by the authors

Figure 6. Total share of gold and INDU Index

Let's consider the results of constructing the optimal portfolio that consists of copper, zinc, INDU Index and SPX Index. In this portfolio the core participants are copper and INDU Index. Their common share fluctuates from $67 \%$ to $100 \%$. Zink and SPX Index are included only in two out of ten portfolios.

Figure 7 shows two efficient frontiers for the last portfolio ("copper_zink") and portfolio that consists of all assets ("full"). "Copper_zink" line lies lower and to the left, so it's risks are higher and its returns are less than the appropriate values for "full" portfolio.

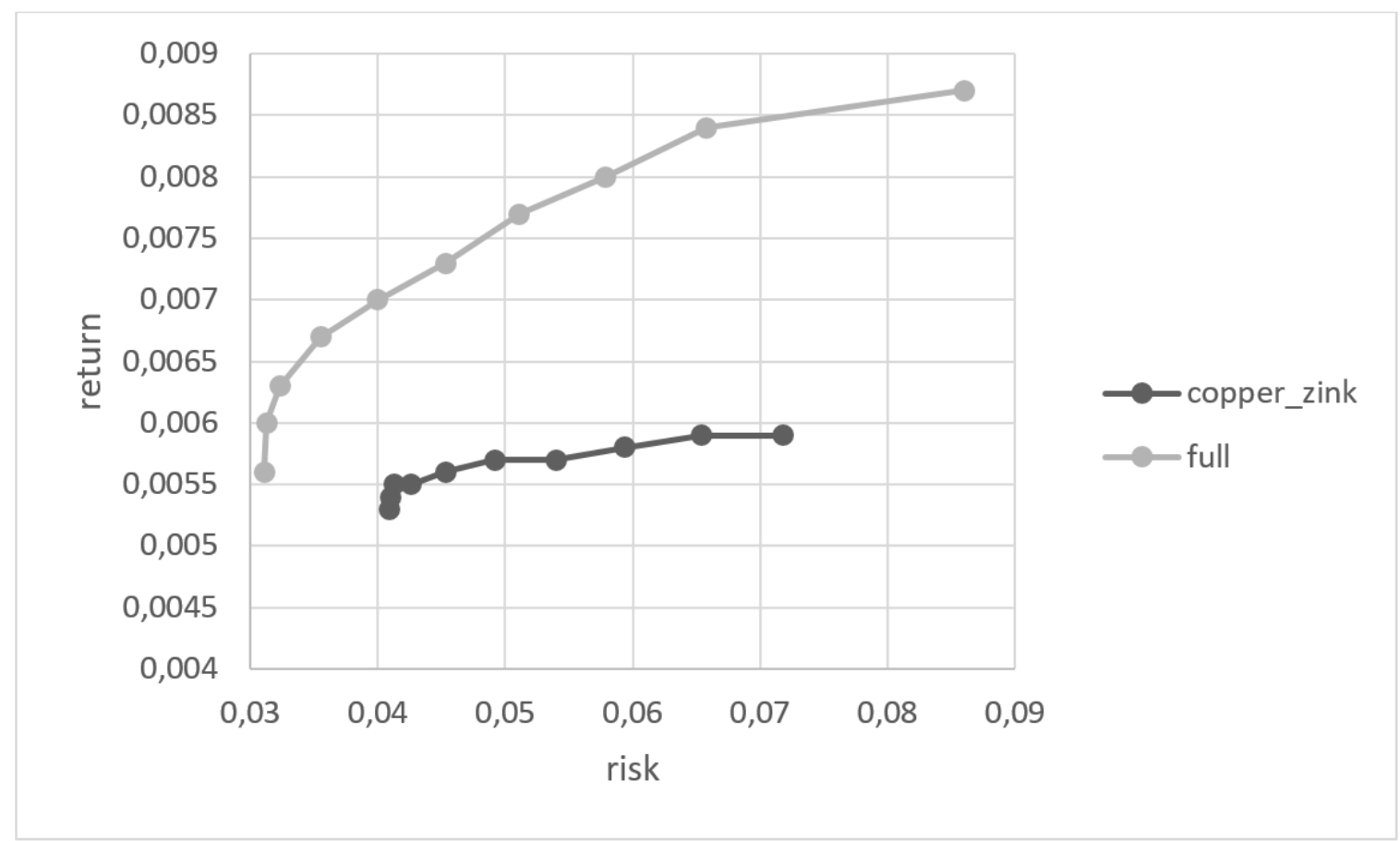

Source: Developed by the authors.

Figure 7. Efficient frontiers for two portfolio sets 
The maximum Sharp ratio among the "copper_zink" portfolios equals 0.13 (risk $=0.0413$; return=0.0055). The portfolio consists of copper (16.67\%), INDU Index (82.15\%) and SPX Index (1.18\%). The maximum drawdown for "copper_zink" portfolio equals $45 \%$.

So, according to the values of sharp ratio and drawdown, the "full" portfolio should be chosen.

Let's consider the results obtained for pair trading strategy.

According to the correlation matrix (see Table 1), the initial set of pairs was formed. It includes only pairs for which correlation coefficient accedes or equals 0.9. All such pairs are listed in Table 3.

Table 3. List of pairs

Source: Developed by the authors

\begin{tabular}{|c|c|c|}
\hline Asset 1 & Asset 2 & Correlation coefficient \\
\hline $\operatorname{tin}$ & gold & 0.93 \\
\hline lead & copper & 0.92 \\
\hline silver & gold & 0.91 \\
\hline $\operatorname{tin}$ & copper & 0.9 \\
\hline tin & silver & 0.9 \\
\hline tin & lead & 0.9 \\
\hline
\end{tabular}

The appropriate ratios are shown on the Figure 8. Analyzing ratios' dynamics, it is possible to assume that those ratios may be traded within mean reverting strategy.

Those ratios were tested on stationarity. The results of augmented Dickey-Fuller test are presented in the Table 4 and Table 5.

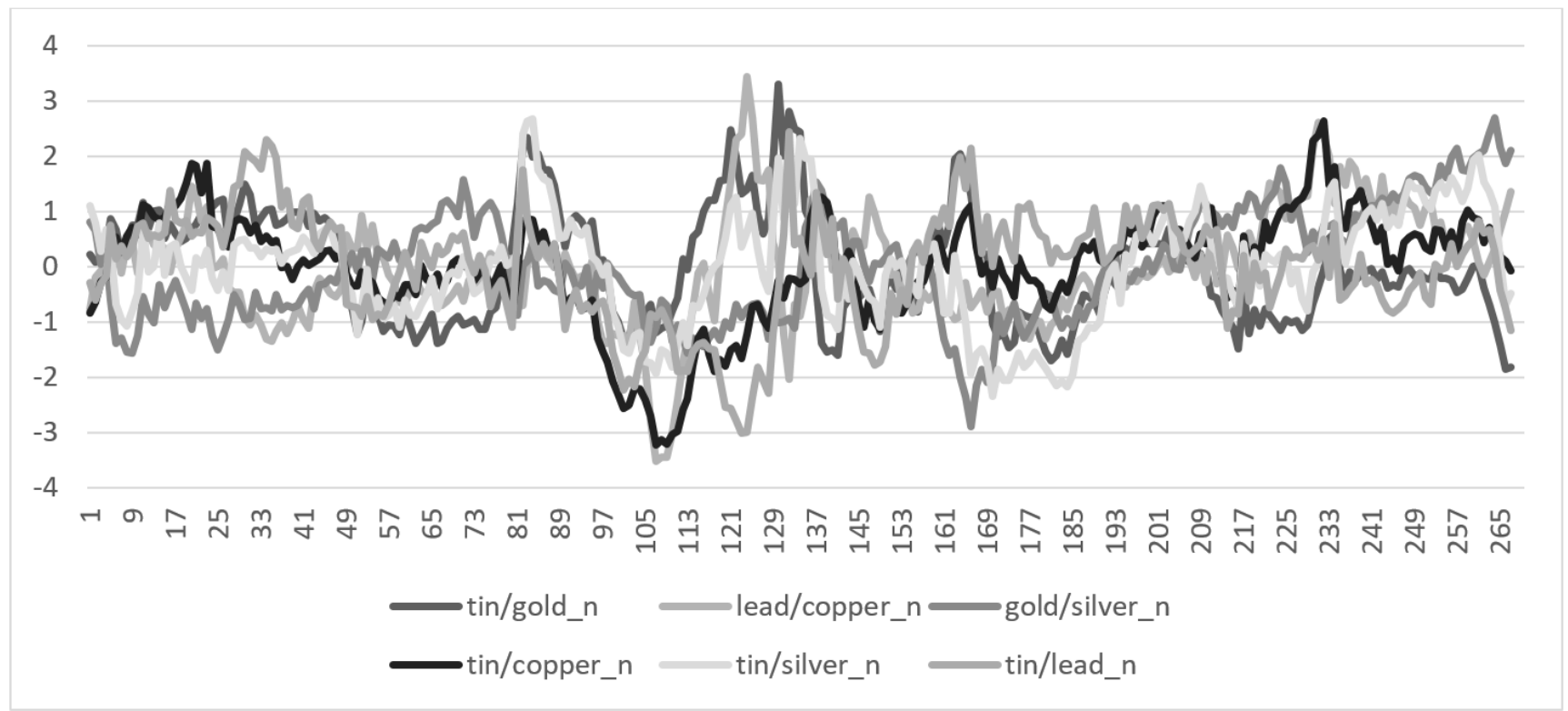

Figure 8. Normalized ratios

Source: Developed by the authors. 
Table 4. Dickey-Fuller test critical values

Source: Developed by the authors

\begin{tabular}{|c|c|}
\hline Levels & Critical values \\
\hline $1 \%$ level & -3.454812 \\
\hline $5 \%$ level & -2.872203 \\
\hline $10 \%$ level & -2.572525 \\
\hline
\end{tabular}

Table 5. Ratios' statistics

Source: Developed by the authors.

\begin{tabular}{|c|c|c|c|}
\hline Asset 1 & Asset 2 & t-Statistic & Probability \\
\hline $\operatorname{tin}$ & gold & -2.953339 & 0.0408 \\
\hline lead & copper & -3.601765 & 0.0063 \\
\hline silver & gold & -2.326504 & 0.1644 \\
\hline $\operatorname{tin}$ & copper & -2.924349 & 0.0439 \\
\hline $\operatorname{tin}$ & silver & -3.968324 & 0.0019 \\
\hline $\operatorname{tin}$ & lead & -4.026506 & 0.0015 \\
\hline
\end{tabular}

So the initial assumption about stationarity was confirmed for such ratios as "lead-copper", "tin-silver" and "tin-gold".

Let's consider the results of applying mean reverting strategy for the chosen ratios. Figure 9 - Figure 11 present graphs of normalized ratios and show the points where the deals were opened and closed. For each graph open points are drawn as triangles, close points are shown as quadrangles. Points of different color correspond to different strategies (when ratio is being bought or sold).

According to Figure 9 ratio "lead/copper" was sold and closed 11 times and was bought and closed 12 times. Total number of successful deals equals 23 . The maximum drawdown during analyzed period was $263 \%$ when selling ratio and $289 \%$ for buying ratio. The maximum number of points between opening and closing deals was 19 (when ratio is being bought) and 37 (when ratio is being sold).

Figure 10 presents "tin/silver" ratio. The ratio was sold and closed 12 times and was bought and closed 10 times. Total number of successful deals equals 24 . The maximum drawdown during analyzed period was $184 \%$ when selling ratio and $140 \%$ for buying ratio. The maximum number of points between opening and closing deals was 26 (buying ratio) and 12 (selling ratio).

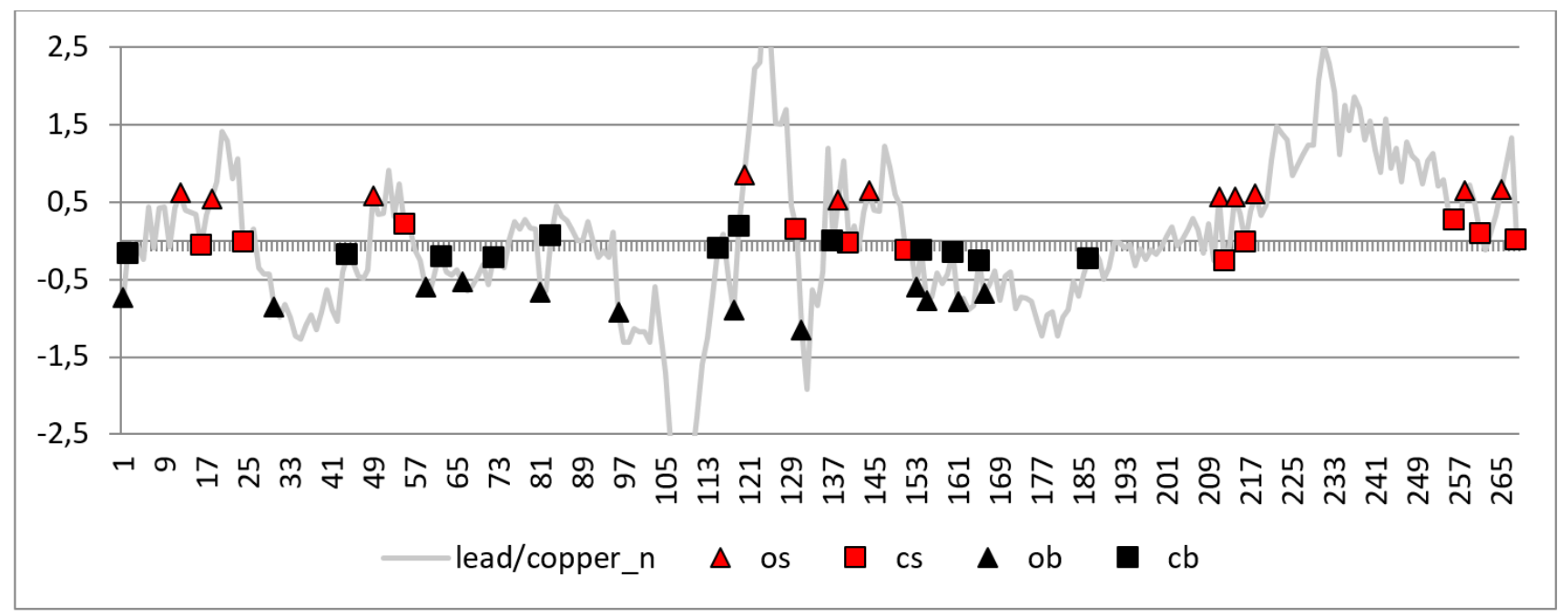

Figure 9. Ratio trading results - lead and copper 


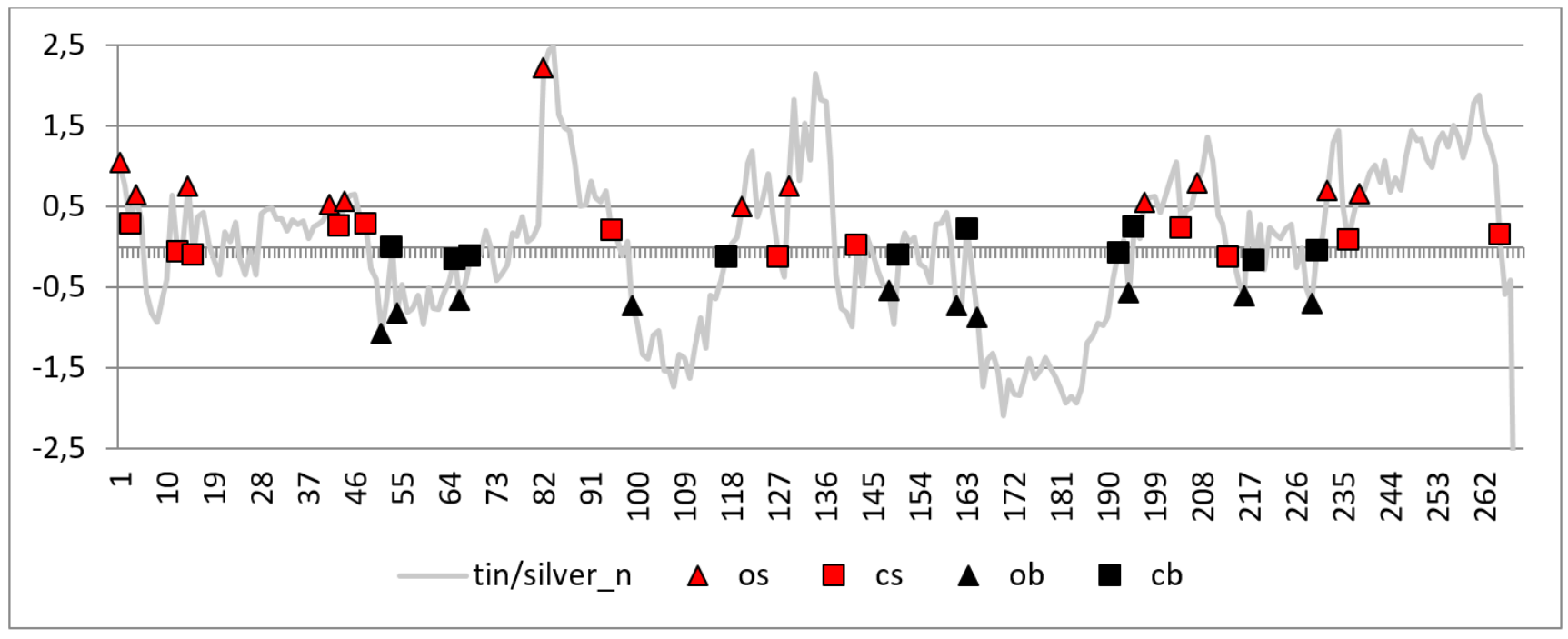

Source: Developed by the authors.

Figure 10. Ratio trading results - tin and silver

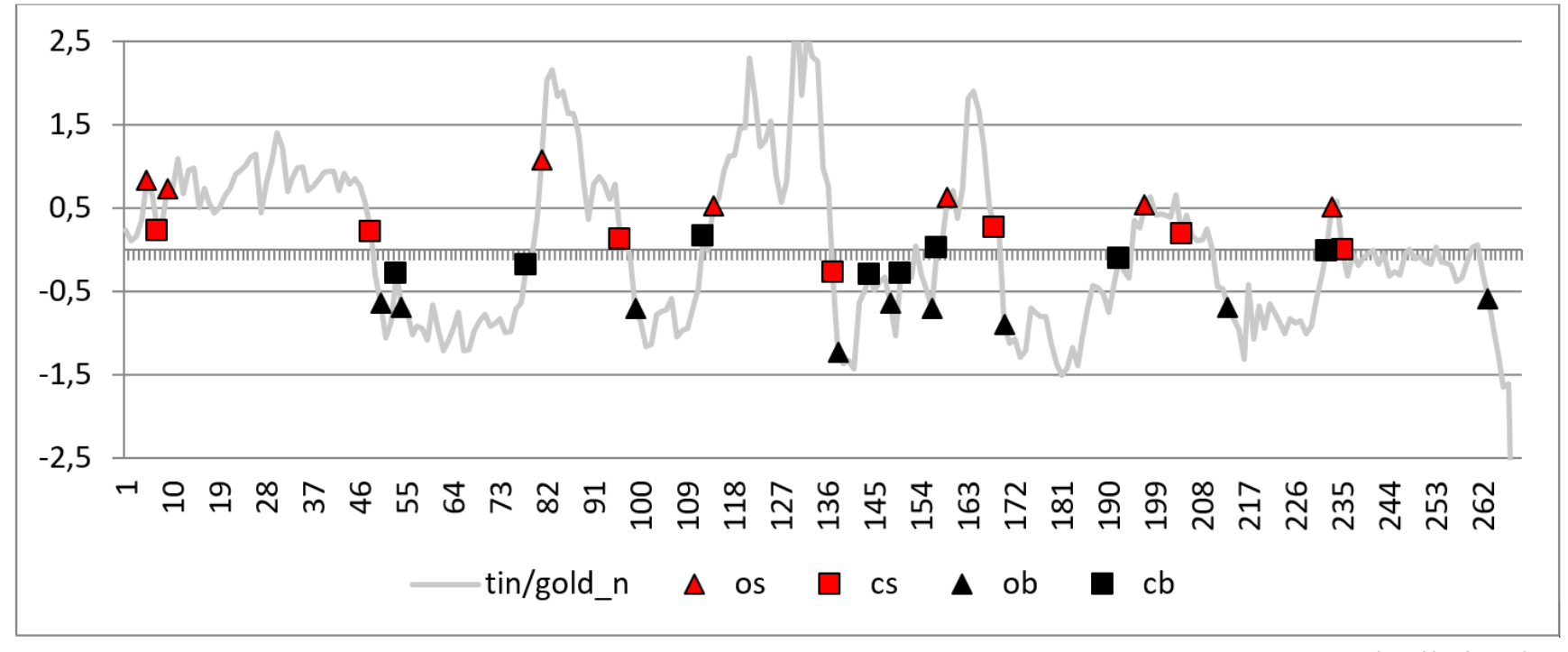

Source: Developed by the authors.

Figure 11. Ratio trading results - tin and gold

Ratio "tin/silver" was sold and closed 7 times and was bought and closed 8 times. One buying deal was not closed during analyzed period. Total number of successful deals equals 15 . The maximum drawdown during analyzed period was $396 \%$ when selling ratio and $97 \%$ for buying ratio. The maximum number of points between opening and closing deals was 23 (when the ratio was being bought) and 38 (when the ratio was being sold).

So, the last ratio has the highest indicator of drawdown and the lowest number of deals. "Lead/copper" has the second position among all ratios. The best one is "tin/silver" ratio with the most suitable drawdown levels.

\section{CONCLUSION}

We have analyzed opportunities of applying investing and arbitrage trading strategies on metals futures market.

The proposed investing strategy is based on Markowitz model that allows to find the efficient frontier for a given set of assets. There were formed two strategies. For the first one named "full" all assets were initially used as input 
variables. But as a result, such instruments as copper and zinc futures were not included into the optimal portfolio. That is why the second strategy was built which had taken into account those outliers ("copper_zink" strategy). The second strategy has appeared riskier, because it's efficient frontier lies lower and to the left of the "full" strategy frontier. The drawdown indicators also have shown the priority of the first strategy. Nevertheless, both strategies can be applied on the real-life market. The final choice will depend on the investors risk acceptance level and the desired return value. The obtained two basic models may be enhanced by the inclusion of additional restrictions on the shares of its members. Moreover, the models should take into consideration the opportunity of not only long but also short positions.

Arbitrage strategy was tested on three core pairs of metal futures - "lead-copper", "tin-silver" and "tin-gold". The pairs were chosen from those ones for which the coefficient of pair correlation for the analyzed period acceded 0.9 and which ratio passed the test for stationarity. The appropriate strategy imply that the normalized ratio should be sold when its value is more than 0.5 and should be bought when its value is less than -0.5 . Both types of deals should be closed when the ratio achieves the level between -0.3 and 0.3 . Three mentioned ratios were ranged and "tin/silver" pair was detected as the best one.

The research has proved that there are the benefits of applying both investing and arbitrage strategies on the metal futures market.

The future researches should take in account the following core points: include short positions into the investing strategy within Markovitz model; test not only LME futures but also derivatives traded on other world exchanges; test the opportunities of calendar spread arbitrage; test both strategies for other timeframes and different time series frequencies; consider transaction costs in both strategies.

\section{REFERENCES}

1. Chen, D., Cui, J., Gao, Y., \& Leilei, W. (2018). Pairs trading in Chinese commodity futures markets: an adaptive cointegration approach. Accounting \& Finance, 57(5), 1237-1264. https://doi.org/10.1111/acfi.12335

2. CME Group (n.d.). Retrieved from https://www.cmegroup.com

3. Do, B., \& Faff, R. (2010). Does simple Pairs trading still work? Financial Analysts Journal, 66(4), 83-95. https://doi.org/10.2469/faj.v66.n4.1

4. Elliott, R., van der Hoek, J., \& Malcolm, W. (2005). Pairs trading. Quantitative Finance, 5(3), 271-276. https://doi. org/10.1080/14697680500149370

5. Fernholz, R., \& Maguire, C. (2007). The statistics of statistical arbitrage. Financial Analysts Journal, 63(5), 46-52. https://doi.org/10.2469/faj. v63.n5.4839

6. Gatev, E., Goetzmann, W., \& Rouwenhorst, K. (2006). Pairs trading: Performance of a relative-value arbitrage rule (NBER Working Paper No. 7032). Review of Financial Studies, 19(3), 797-827. https://doi.org/10.3386/w7032

7. Göncü, A., \& Akyildirim, E. (2016). Statistical Arbitrage with Pairs Trading. International Review of Finance, 16(2), 307-319. https://doi. org/10.1111/irfi.12074

8. Hull, J. (2012). Options, Futures, and Other Derivatives (Global Edition) (896 p.). London: Pearson PLC. Retrieved from https://www. amazon.co.uk/Options-Futures-Other-Derivatives-Global/dp/1292212896

9. Krauss, C. (2017). Statistical Arbitrage Pairs Trading Strategies: Review and Outlook. Journal of Economic Surveys, 31(2), 513-545. https:// doi.org/10.1111/joes.12153

10. Mangram, M. (2013). A Simplified Perspective of the Markowitz Portfolio Theory. Global Journal of Business Research, 7(1), 59-70. Retrieved from https://ssrn.com/abstract $=2147880$

11. Markowitz, H. (1952). Portfolio Selection. The Journal of Finance, 7(1), 77-91. https://doi.org/10.2307/2975974

12. Nijman, T., de Roon, F., \& Veld, C. (1996). Pricing Term Structure Risk in Futures Markets (CentER Discussion Paper. Vol. 1996-78) (25 p.). Tilburg: Finance. https://research.tilburguniversity.edu/en/publications/pricing-term-structure-risk-in-futures-markets-2

13. Sharpe, W. (1964). Capital Asset Prices: A Theory of Market Equilibrium under Conditions of Risk. The Journal of Finance, 19(3), 425-442. https://doi.org/10.2307/2977928

14. Stübinger, J., \& Bredthauer, J. (2017). Statistical Arbitrage Pairs Trading with High-frequency Data. International Journal of Economics and Financial Issues, 7(4), 650-662. Retrieved from https://www.econjournals.com/index.php/ijefi/article/view/5127

15. Tobin, J. (1969). A General Equilibrium Approach to Monetary Theory. Journal of Money, Credit and Banking, 1(1), 15-29. https://doi. org/10.2307/1991374

16. Vidyamurthy, G. (2004). Pairs Trading: Quantitative Methods and Analysis (224 p.). USA: John Wiley \& Sons, Inc. Retrieved from https:// www.wiley.com/en-us/Pairs+Trading\%3A+Quantitative+Methods+and+Analysis-p-9780471460671

17. Vollmer, M. (2015). A Beta-return Efficient Portfolio Optimisation Following the CAPM. Wiesbaden: Springer Gabler. https://doi. org/10.1007/978-3-658-06634-5 